\title{
ОРТОДОНТІЯ
}

УДК 616.714-071

Al-cablany Ebrahem Hezam, Makarova O.M., Kuroiedova V.D.

\section{CEPHALOMETRIC SKELETAL COMPARATIVE ANALYSIS BETWEEN LEFT AND RIGHT SIDE OF SKULL FOR TWO AGE GROUPS PATIENTS WITH CLASS ONE MALOCCLUSION BY THREE DIMENSIONAL CONE-BEAM COMPUTED TOMOGRAPHY}

\author{
Ukrainian Medical Stomatological Academy, Poltava, Ukraine
}

\section{Introduction}

Cephalometric analysis is an important orthodontics diagnostic tool for evaluation of dentofacial morphology, treatment plan and follows up. It provides a clear image of the skeletal changes that occur in the process of growth and treatment of patients. But the 2D lateral cephalometric isn't used to give us clear idea for comparison between two sides of face and symmetry of skull in which the analysis usually from one (right) side with two plane. In the lateral cephalogram the patient head is positioned with the left side of face next to the image receptor, with the midsagittal plane parallel to the image receptor and the Frankfort plane parallel to the floor. An X-ray beam should be collimated (from right side) to the size of receptor at left side. Because of the projection geometry, structure away from the receptor will be magnified more than the structure close to receptor. Magnification is calculated by dividing the distance from the source of radiation to the image receptor (SID) by the distance from the source to the object of interest (SOD). Based on this calculation, it is easy to see that the right and left sides of the skull will be different sizes in a lateral cephalogram [1].

In the United States, lateral cephalograms are conventionally taken with the left side of the patients head closest to the film. In Europe, however, the convention is to place the right side of patient head closest to film [2]. According to in vitro study of B. Callouel, the result from 2 techniques isn't the same, because of the divergent nature of $x$-ray, the structure of the craniofacial complex that are the farthest from the film will be magnified more than those that are closer to the film.

Shortly after the discovery of $\mathrm{x}$-rays by Wilhelm Conrad Roentgen (1895) the use of the first facial and cranial radiographs was reported as early as
1896 by Rowland and later by Ketcham and Ellis. B. $\mathrm{H}$. Broadbent used lateral cephalograms in his private practice in 1921 [3].

First registration for roentgenograms of head was made in 1896; Ketchman published first lateral roentgenograms of the head in 1919 [4].

The development and introduction in medical practice of the computed tomography (CT) were represented as an important contribution to the orthodontic radiological diagnosis by Sir Godfrey Hounsfield in 1971, overcoming the limits of the previous methods, while the cone-beam computed tomography began to appear more late 1990 [5].

During the last few years the 3D cephalometric analysis able to describe anatomical landmarks both on hard and soft tissues has been introduced [6]. CBCT is currently being used with orthodontic patients since it offers three-dimensional craniofacial imaging as an alternative to conventional radiography and computed tomography (CT). Moreover, the images produced with CBCT are not magnified; CBCT may replace some of the diagnostic tools used in orthodontics, such as two-dimensional (2D) cephalometry. Today, the most clinicians are replacing conventional radiographic records with $\mathrm{CBCT}$. It can provide a series of slides which are then reconstructed in $3 \mathrm{D}$, which give us much more information of the structures studied [7].

Facial asymmetry is commonly observed in the most population and it is an individualized characteristic, asymmetry refers to the bilateral difference between such components [8]. A perfect bilateral symmetry almost never exists in the human body where it in soft tissues or hard tissues, with old or young age. Computed tomography is considered an optimal diagnostic method for asymmetry assessment [9].

The purpose of this study were to conduct comparative cephalometric analysis between left and 
right side of head (lateral, frontal) and evaluate the skeletal facial symmetry in patients with class one malocclusion by using 3D CBCT. Two age groups were aid to known if there are differences in craniofacial growth between left and right side for young samples as increase of the brain during prenatal and early postnatal life that thrusts the calvarial bony plates outward and the midface forward and downward [10].

The cranial cavity achieves $87 \%$ of its adult size of 2 years, $90 \%$ of 5 years and $98 \%$ from 8 to 15 years. Between 15 years and adulthood the growth changes are the mostly secondary to the pneumatization of the frontal sinuses and thickening of the anterior part of the frontal bone [11].

\section{Materials and Methods}

Twenty 3D CBCT for patients (7 males, 13 females) with age ranging from 8 to 34 year were screened for the following criteria.

- All subjects have normal skeletal relation.

- Good facial symmetry/proportion was shown.

- None of the subjects should have undergone any orthodontic or maxillofacial/plastic surgery in the past.

- Cases were chosen for inclusion only on the ba- sis of balance of facial parts, and quality of parts (skin color, beautiful eyes, hair style or color) was disregarded.

- Handwork measurement analysis (without software analysis program was used) except the landmarks determination.

- Ethical Approval and acquisition of Informed Consent was obtained for all cases.

All cases had not undergone previous orthodontic treatment; they came to Orthodontic Department of Ukrainian Medical Stomatological Academy for orthodontics consultation. Two different age groups of patients were from May 2017 to January 2019: 10 subjects in group $A$ (age $\leq 14$ 'yr') and 10 subjects in group B (age $>14$ ' $y r^{\prime}$ '). 3D CBCT (advanced 3dimaginag software Ez3d2009) was used for all cases. It was recorded by the same operator and taken in Natural Head Position (NHP) and simultaneously in centric occlusion and lips in repose. The measurement was used with 11 angular (anteroposterior frontal) and 4 liner as shown in (tables 2). The cephalometric analysis was recorded from right and left.

Unilateral and bilateral landmarks parameters were used for comparative reasons between right and left side of the head ( table 1).

Table (1) landmarks definitions

\begin{tabular}{|l|l|}
\hline \multicolumn{1}{|c|}{ Variables } & \multicolumn{1}{c|}{ Definition } \\
\hline Nasion (Na point) & The anterior point of the intersection between the nasal and frontal bones. \\
\hline Pogonion (Pog) & The most anterior point on the contour of the chin. \\
\hline S point & The midpoint of the cavity of sella turcica or the center of pituitary fossa. \\
\hline $\begin{array}{l}\text { Isi-Incision Superius } \\
\text { Incisalis }\end{array}$ & Incision superius incisalis is the incisal tip of the most anterior maxillary central incisor. \\
\hline $\begin{array}{l}\text { Isa-Incision Superius } \\
\text { Apicalis }\end{array}$ & The upper incisor apex is the root apex of the most prominent upper incisor. \\
\hline lii-Incision inferius incisalis & The incision inferius is the incisal tip of the most labial mandibular central incisor. \\
\hline lia-Incision inferius apicalis & The lower incisor apex is the root apex of the most prominent lower incisor. \\
\hline Gonion (Go) & The bilaterial midpoint of the contour connecting the ramus and mandibular body. \\
\hline Gnathion (Gn) & The center of the inferior point on the mandibular symphysis. \\
\hline Anterior nasal spine (ANS) & The most anterior point of the nasal floor tip of pre-maxilla on mid-sagittal plane. \\
\hline A point & $\begin{array}{l}\text { The deepest midline point on the premaxilla between the anterior nasal spine and } \\
\text { prosthion. }\end{array}$ \\
\hline Menton (Me) & The most inferior point on the mandibular symphysis. \\
\hline Condylon (Cd) & The upper midpoint of the mandibular condyle. \\
\hline B point & Innermost point on the contour of the mandible. \\
\hline $\begin{array}{l}\text { Zygomaticofrontal suture } \\
\text { (Z) }\end{array}$ & $\begin{array}{l}\text { The bilateral, anatomic, hard tissue PA cephalometric landmark at midpoint in the } \\
\text { Zygomaticofrontal suture. }\end{array}$ \\
\hline Porion (Po) & Bilateral most superior points of auditory meatus. \\
\hline Orbital (Or) & $\begin{array}{l}\text { Bilateral the lowest point on the lower margin of each orbit. It is identified by palpation } \\
\text { and is identical to the bony orbitale. }\end{array}$ \\
\hline Mx-Maxillare & $\begin{array}{l}\text { The bilateral, anatomic, hard tissue PA cephalometric landmark, Maximum concavity } \\
\text { on the contour of the maxilla between the first molar and malare. }\end{array}$ \\
\hline Ag-Antegonion & $\begin{array}{l}\text { The bilateral, anatomic, hard tissue PA cephalometric landmark. As it highest point in } \\
\text { the antegonial notch (left and right). }\end{array}$ \\
\hline In-or infraorbital & Bilateral anatomic hard tissue at the center of inrfaorbital foramen. \\
\hline
\end{tabular}

The following reference planes were used: Frankfort Horizontal Plane (FHP)

- Mandibular Plane (MP): A plane connecting the points Gonion and Menton.

Seven skeletal cephalometric angular meas- urements, ANB, Z-GO-ME, PO-GO-ME, FMA, FHA, FH-Z-GO. and one dental cephalometric angular measurement (Inter incisal) were used from both sides for right and left central incisors.

Four skeletal frontal angular measurement, AG- 
AG to midline, inOR-inOR to midline, $M X-M X$ to midline, Z-Z to midline were used of frontal view ( table 2 ) (figure 3 ).

Four linear measurements were used from right and left side as following.

- Posterior mandibular height (CD-GO): The linear distance from condyle (CD) to Gonion (GO).

- PO-GO: The linear distance from porion (PO) to Gonion (GO).
- OR-GN: The linear distance between Orbital (OR) and Gnathion (GN).

- OR-ANS: The linear distance between Orbital (OR) and Anterior nasal spine (ANS).

The results were statistically analyzed to establish norms for the right side as well as to compare them with the findings of left side for whole sample and subsamples.

\begin{tabular}{|l|l|}
\hline \multicolumn{1}{|c|}{ Angle } & \multicolumn{1}{c|}{ Definition } \\
\hline ANB & The angle formed between A point, nasion, B point. \\
\hline Z-Go-Me & Angle formed between the Z-Go line and the line drawn along Go and Me \\
\hline Po-Go-Me & Angle formed between the Po-Go line and the line drawn along Go-Me \\
\hline FH-M OR FMA & $\begin{array}{l}\text { The Frankfort-mandibular plane angle is formed by the intersection of the Frankfort } \\
\text { horizontal plane and the mandibular plane. }\end{array}$ \\
\hline FH-A & Angle is formed by the intersection of the Frankfort horizontal plane and A-point \\
\hline FH-Z-Go & $\begin{array}{l}\text { Superior angle that formed by the intersection of the Frankfort horizontal plane and the } \\
\text { line drawn along Z-Go. }\end{array}$ \\
\hline Inter incisal & Angle formed between the long axes of upper and lower incisors. \\
\hline Z-Z to midline & $\begin{array}{l}\text { Angles (left ,right) is formed by the intersection of the vertical midline to horizontal Z-Z } \\
\text { line from frontal view. }\end{array}$ \\
\hline inOr-inOr to midline & $\begin{array}{l}\text { Angles (left, right) is formed by the intersection of the vertical midline to horizontal } \\
\text { infraorbitals fossae line from frontal view. }\end{array}$ \\
\hline Mx-Mx to midline & $\begin{array}{l}\text { Angles (left, right) is formed by the intersection of the vertical midline to horizontal Mx- } \\
\text { Mx line from frontal view. }\end{array}$ \\
\hline Ag-Ag to midline & $\begin{array}{l}\text { Angles (left, right) is formed by the intersection of the vertical midline to horizontal Ag- } \\
\text { Ag line from frontal view. }\end{array}$ \\
\hline
\end{tabular}
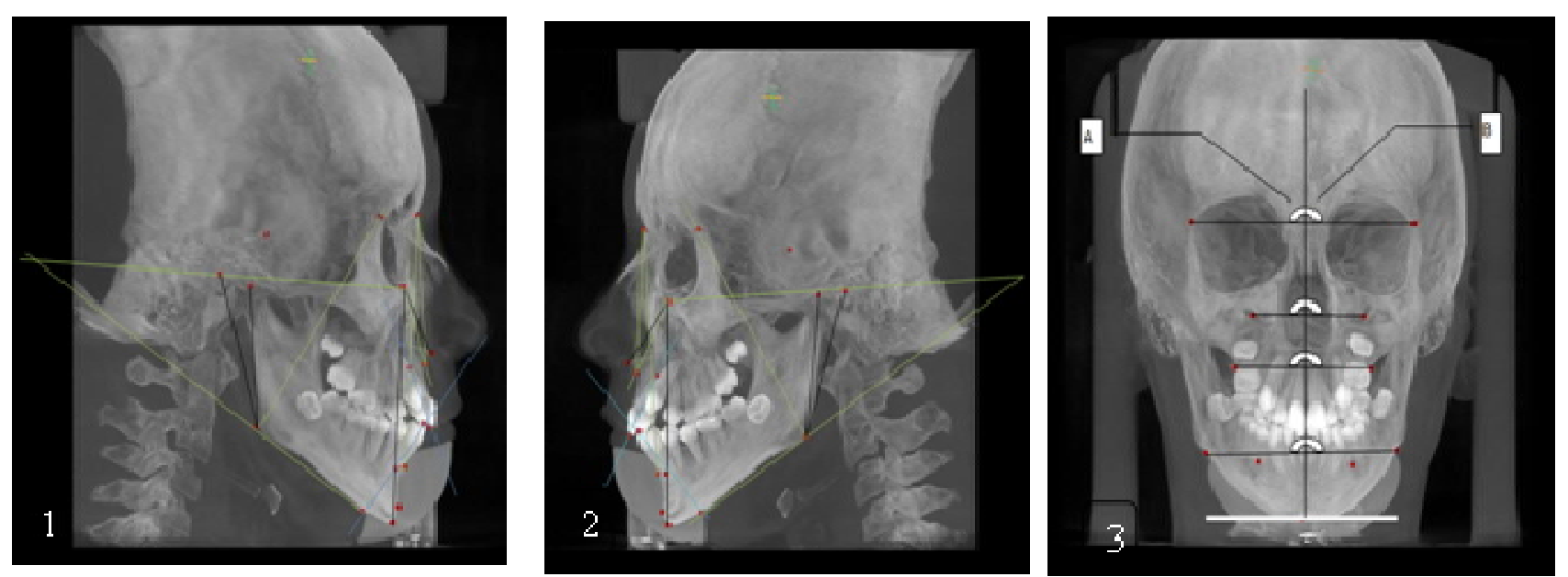

Figures (1) right side parameters (A)yellow color represent the skeletal plane of angles ANB, Z-GO-ME, PO-GO-ME, $F M A, F H-A, F H-Z-G O .(B)$ black color represent the liner measurements mm CD-GO, PO-GO, OR-GN, OR-ANS. (C)blue color represent the dental plane of interincisal angle. (2) left side parameters .(3) skeletal frontal angular measurement from $(A)$ right and (B)left, depend on intersection of midline with planes of $A G-A G$, inOR-inOR, MX-MX, Z-Z

\section{Results}

Normal values were calculated as mean, standard deviation (SD) for reference in the treatment procedure. Significance of the difference between the both sides was tested with Chi -test. Statistical analysis showed that the two side were similar in the most but not in all measurements.

As shown in the result tables the dental factors (interincisal angle) showed a higher value differences from left to right, while frontal view factors showed a lower value differences The remaining means were not statistically different between them.

Comparisons between the right and left side of skull for whole sample.

As shown in (table 3) from anteroposterior measurements the difference in the ANB angle between the right and left sides $(-0.183)$ where it at right 4.238095 with SD 1.68 while it at left side 4.42 with SD 1.74 . p-value $(p<0.99)$ were not statistically significant, ANB angle represent relationship of both arches to frontal bone (unilateral landmarks).from the result the most symmetric angle for both side it was inOR-inOR where the DF $=0$.

Comparisons between the right and left side of skull for group A contains younger age sample. 


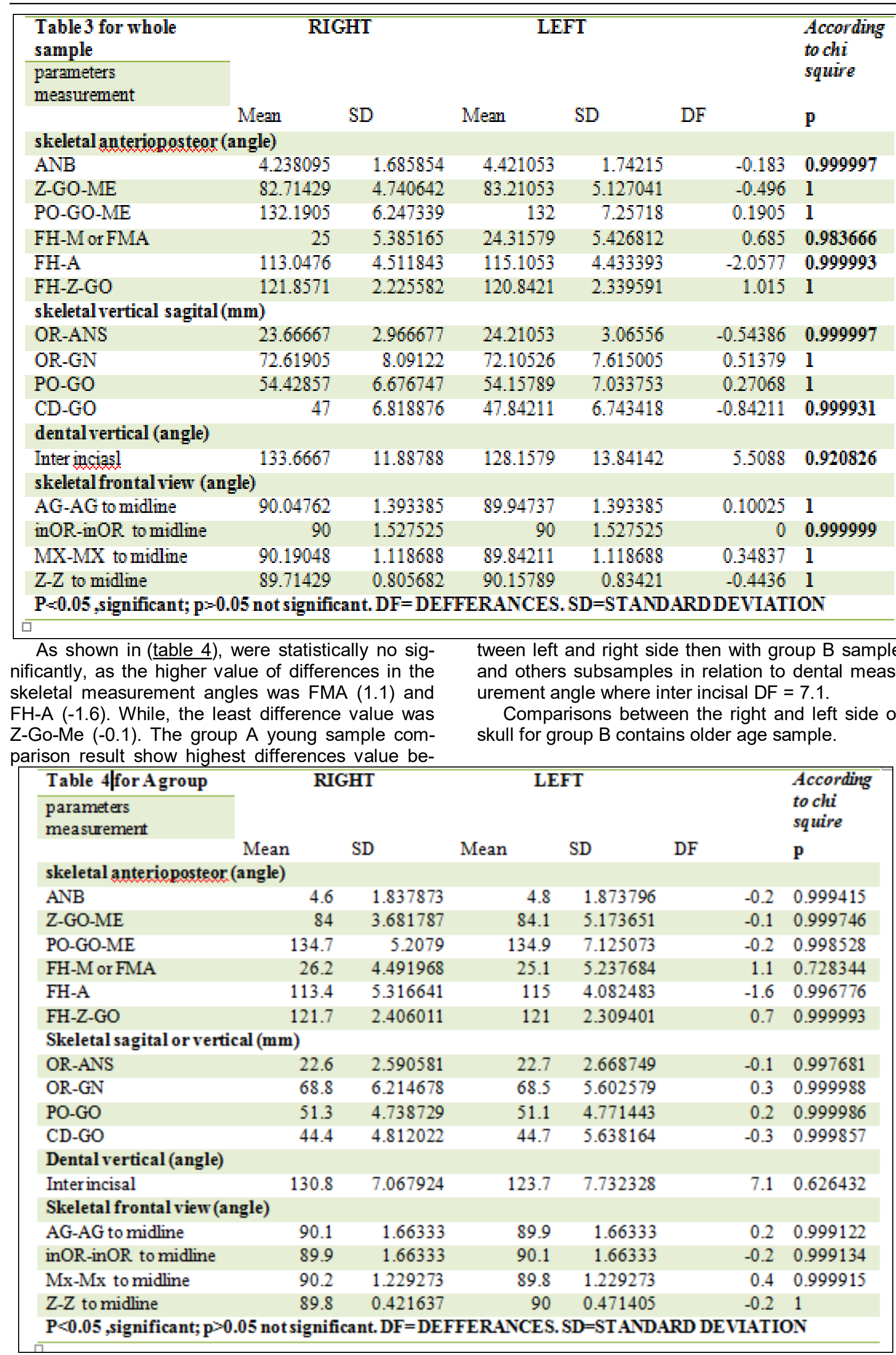


As shown in (table 5), the older sample more symmetrical than A sample younger sample. The higher value of differences in the skeletal meas- urement angles from right to left was $\mathrm{FH}-\mathrm{A}(-1.8)$ and $\mathrm{FH}-\mathrm{Z}-\mathrm{GO}$ (1.2). While, the least difference value was $A G-A G(0)$.

\begin{tabular}{|c|c|c|c|c|c|c|}
\hline \multirow{2}{*}{$\begin{array}{l}\text { Table } 5 \text { B sample } \\
\text { parameters } \\
\text { measurement }\end{array}$} & \multicolumn{2}{|c|}{ RIGHT } & \multirow{2}{*}{\multicolumn{2}{|c|}{ LEFT }} & \multirow[b]{3}{*}{ DF } & \multirow{3}{*}{$\begin{array}{l}\text { According } \\
\text { to chi } \\
\text { squire } \\
\mathrm{p}\end{array}$} \\
\hline & \multirow[b]{2}{*}{ Mean } & \multirow[b]{2}{*}{ SD } & & & & \\
\hline & & & Mean & SD & & \\
\hline \multicolumn{7}{|c|}{ skeletal anterioposteor (angle) } \\
\hline ANB & 3.777778 & 1.481366 & 4 & 1.581139 & -0.22222 & 0.996123 \\
\hline Z-GO-ME & 81.55556 & 5.637178 & 82.22222 & 5.190804 & -0.66666 & 0.999279 \\
\hline PO-GO-ME & 129.3333 & 6.344289 & 128.7778 & 6.260547 & 0.5555 & 0.999959 \\
\hline FH-M or FMA & 23.66667 & 6.22495 & 23.44444 & 5.811865 & 0.22223 & 0.99248 \\
\hline FH-A & 113.3333 & 3.741657 & 115.2222 & 5.044249 & -1.8889 & 0.998534 \\
\hline $\mathrm{FH}-\mathrm{Z}-\mathrm{GO}$ & 121.8889 & 2.14735 & 120.6667 & 2.5 & 1.2222 & 0.999968 \\
\hline \multicolumn{7}{|c|}{ Skeletal sagital or vertical (mm) } \\
\hline OR-ANS & 24.77778 & 3.073181 & 25.88889 & 2.666667 & -1.11111 & 0.999036 \\
\hline OR-GN & 76.33333 & 8.381527 & 76.11111 & 7.801353 & 0.22222 & 0.999979 \\
\hline PO-GO & 57.77778 & 7.084804 & 57.55556 & 7.812028 & 0.22222 & 0.999069 \\
\hline CD-GO & 50 & 7.745967 & 51.33333 & 6.363961 & -1.33333 & 0.95363 \\
\hline \multicolumn{7}{|l|}{ Dental vertical (angle) } \\
\hline Inter incisal & 135.2222 & 15.81754 & 133.1111 & 17.64543 & 2.1111 & 0.919729 \\
\hline \multicolumn{7}{|c|}{ Skeletal frontal view (angle) } \\
\hline AG-AG to midline & 90 & 1.118034 & 90 & 1.118034 & 0 & 0.999915 \\
\hline inOR-inOR to midline & 90.11111 & 1.452966 & 89.88889 & 1.452966 & 0.22222 & 0.99934 \\
\hline $\mathrm{Mx}-\mathrm{Mx}$ to midline & 90.11111 & 1.054093 & 89.88889 & 1.054093 & 0.22222 & 0.999943 \\
\hline $\mathrm{Z}-\mathrm{Z}$ to midline & 89.66667 & 1.118034 & 90.33333 & 1.118034 & -0.66666 & 0.999884 \\
\hline \multicolumn{7}{|c|}{$\mathrm{P}=0.05$, significant; $\mathrm{p}=0.05$ not significant. $\mathrm{DF}=\mathrm{DEFFERANCES.SD}=\mathrm{STANDARDDEVIATION}$} \\
\hline
\end{tabular}

\section{Discussion}

There are numerous factors which should be considered when applying the results of this investigation. The accuracy of measurement distances may be affected by a reduction in image quality due to tissue attenuation, metallic artifacts, patient motion and variation in scanning protocol. Therefore, it would be expected that during selection of cases was consider the normal symmetry of face at smiling, mouth opening and profile appearance. 3-mm asymmetry was considered abnormal for smiling. Asymmetry was recognized when both the eyebrow and oral commissure have more than a 3-mm difference [12].

This study showed that the right side measurements not exactly equal and symmetry the left side measurement but there were little differences, that also, depend on the age and sex. The young sample show less symmetry than olde. There were the dental factors (inter incisal) least symmetric especially at mixed dentition while, the frontal skeletal factor most symmetrical.

The female patients show less symmetry than male. The frontal view show more symmetrical than lateral anteroposterior view. The dental angle measurement at all sample show highest value differences between left and right side. The angles that formed by Unilateral landmarks (ANB) show more symmetrical result than the angle that formed by bilaterial landmarks. The infraorbital bilateral landmark it was the most symmetrical point for whole sample, where inOR-inOR to midline angle $=$ 90. from both side.

Extra-cranial reference line was used instead of an intracranial reference line, which is essential for cephalometric analysis based on NHP because patients have considerable biological variations in inclination.

In this study manual measurement analysis were used rather than software programs analysis, because here used new and different parameters like, Z-GO-ME or FH-Z-GO. The software programs that used in orthodontics cephalometric analysis measurements are not statistically significant mostly with manual analysis measurements [13].

Also, many studies have compared available cephalometric analysis software programs and found no clinically significant difference between the measured values [14].

In this study was considered relation of facial bone growth to above landmarks selection, where the maxillary complex is surrounded by a system of sutures that allows the growth and displacement of the various bones both anteroposteriorly and laterally. The circummaxillary suture system includes the zygomaticomaxillary, frontozygomatic, sphenopalatine, and palatomaxillary sutures [15]. The frontozygomatic bilaterial landmark point $(Z)$ was used as criteria for comparison of both side and its angulation with mandibular and maxillary bone (Z-GOME, Z-Z to midline). 
The growth on the head of the condyle occurs in an upward and backward direction. Mandibular growth is expressed as a downward and forward displacement. The growth at the condyles compensates for the vertical displacement of the mandible and accommodates for the eruption of the teeth vertically. On the other hand, the bone resorption at the anterior border and deposition at the posterior border of the two rami account for the anteroposterior growth of the mandibular rami and body [16].

The CD-GO liner distances of right was compared with left that represent the vertical height of posterior of mandibular, while the PO-GO measure the mandibular angle to portion point of partial bone from both sides. Also, the OR-ANS and OR-GN liner distances may represent the anterior vertical growth of half lower face of both sides. Also, the selection of two age groups was allowed to make a comparison between them and identified ratio of symmetry of both side.

According to Bjork [17] the bone change direction (7-19 years old) was related to (SN plane) downward and forward. But the scientist did not specify or mention any differences between left and right side bone change with large individual variation.

\section{Conclusion}

Measurements of skeletal analysis performed by 3D CBCT cephalograms from right side were found to be similar to left side. So, we can use the left analysis for orthodontics diagnosis as right side. Also, the both side analysis can be used for symmetric analysis reasons.

\section{Compliance with Ethical Standards}

Ethical approval: All procedures performed in this study involving human participants (3D tomography $x$-ray) were in accordance with the ethical standards of the institutional and/or national research committee in 1964 in Helsinki.

\section{References}

1. Katherine Kula, A.G., Cephalometry in Orthodontics 2D and 3D-Reduced.pdf. 2018, USA quintessence 9-10.

2. Caillouel, B., REVIEWS AND ABSTRACTS-A quantitative analysis of the difference between rightand left-facing lateral cephalograms. American

Journal of Orthodontics and Dentofacial Orthopedics, 2002. 121(3): p. 329.

3. Broadbent Sr, B., B. Broadbent Jr, and W.H. Golden, Bolton standards of dentofacial development growth, St. Louis, CV Mosby, 1975.

4. Flis, P., et al., Orthodontics. Kyiv, MEDICINE, 2008: p. 221-242.

5. Katherine Kula , A.G., Cephalometry in Orthodontics 2D and 3D-Reduced.pdf. 2018, USA: quintessence 14-15.

6. Harrell, W.E., et al., Applications of CBCT in Orthodontics, in Maxillofacial Cone Beam Computed Tomography. 2018, Springer. p. 645714.

7. Dindaroğlu,, F. and E. Yetkiner, Cone Beam Computed Tomography in Orthodontics. Turkish journal of orthodontics, 2016. 29(1): p. 16-21.

8. Ko, E.W.-C., C.S. Huang, and Y.R. Chen, Characteristics and corrective outcome of face asymmetry by orthognathic surgery. Journal of Oral and Maxillofacial Surgery, 2009. 67(10): p. 22012209.

9. Palomo, J.M., et al., A longitudinal 3-dimensional size and shape comparison of untreated Class I and Class II subjects. American journal of orthodontics and dentofacial orthopedics, 2005. 127(5): p. 584591.

10. Moss, M.L. and L. Salentijn, The capsular matrix. American journal of orthodontics, 1969. 56(5): p. 474-490.

11. Graber, T., Orthodontics: principles and practice, ed. 3, Philadelphia, 1972. WB Saunders Company.

12. Chebib, F. and A. Chamma, Indices of craniofacial asymmetry. The Angle Orthodontist, 1981. 51(3): p. 214-226.

13. Guedes, P.d.A., et al., A comparative study of manual vs. computerized cephalometric analysis. Dental Press Journal of Orthodontics, 2010. 15(2): p. 44-51.

14. Baskin, H. and G.J. Cisneros, A comparison of two computer cephalometric programs. Journal of clinical orthodontics: JCO, 1997. 31(4): p. 231-233.

15. Knott, V., Change in cranial base measures of human males and females from age 6 years to early adulthood. Growth, 1971. 35(2): p. 145-158.

16. Bishara, S.E. and W. Saunders, Textbook of orthodontics. 2001: Saunders Book Company. 4149.

17 Björk, A., Sutural growth of the upper face studied by the implant method. Acta Odontologica Scandinavica, 1966. 24(2): p. 109-127.

Стаття надійшла: 26.12.2019 року

\section{Summary}

Objective: The purpose of our research was to study comparative cephalometric analysis between left and right sides of head and evaluate the skeletal facial symmetry in patients with class 1 malocclusion by $3 \mathrm{D}$ Cone-beam computed tomography (CBCT). Materials and Methods: Pre-treatment by 3D Cone-beam computed tomography radiographs for 20 patients of two age groups with class 1 malocclusion was undergone for 11 angular and 4 liner measurements from right and left sides, anteroposterior, vertical and frontal view by hand except the hard landmarks determination. Chi-test was used to compare the result of both sides ( $P$ $<0.05)$. Results: No difference was found between left and right analysis for linear measurements as for the angular cephalometric measurements. Conclusion: Measurements of skeletal analysis by 3D CBCT cephalograms from right side were found to be similar to left side. So, we can use the left analysis for orthodontics diagnosis as right side. Also, the both sides analysis can be used for symmetric analysis reasons.

Key words: Cephalometric, analysis, symmetry, cone-beam computed tomography, measurement, orthodontics. 


\section{Резюме}

Мета дослідження - порівняти цефалометричні показники лівого й правого боків черепа в пацієнтів із І класом ЗЩА за допомогою конусно-променевої комп'ютерної томографії (СВСТ). Матеріали і методи: на 3D-рентгенограмах 20 пацієнтів двох вікових груп із І класом ЗЩА було проведено 11 кутових і 4 лінійні вимірювання з правого й лівого боків. Результати: статистично достовірної різниці між лівою й правою половинами не виявлено. Висновки: аналіз вимірювань скелета за допомогою 3Dцефалограм із правого й лівого боку в пацієнтів із I класом ЗЩА статистично не відрізняється. Отже, при I класі ЗЩА можна використовувати і лівий, і правий боки для цефалометричного аналізу.

Ключові слова: цефалометричний, аналіз, симетрія, конусно-променева комп'ютерна томографія, вимірювання, ортодонтія.

\section{Резюме}

Цель исследования - сравнить цефалометрические показатели левой и правой сторон черепа у пациентов с I классом ЗЧА с помощью конусно-лучевой компьютерной томографии (СВСТ). Материалы и методы: на 3D-рентгенограммах 20 пациентов двух возрастных групп с I классом ЗЩА были проведены 11 угловых и 4 линейные измерения с правой и левой сторон. Результаты: статистически достоверной разницы между левой и правой половинами не обнаружено. Выводы: анализ измерений скелета с помощью 3D-цефалограмм с правой и левой стороны у пациентов с I классом ЗЧА статистически не отличается. Следовательно, при I классе ЗЧА можно использовать и левую, и правую стороны для цефалометрического анализа.

Ключевые слова: цефралометрический, анализ, симметрия, конусно-лучевая компьютерная томография, измерения, ортодонтия. 